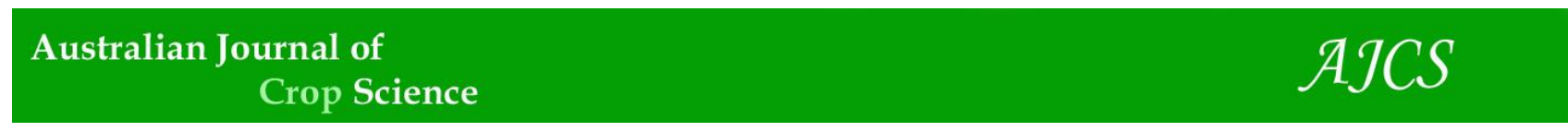

AJCS 10(8):1158-1163 (2016)

ISSN:1835-2707

DOI: $10.21475 /$ ajcs.2016.10.08.p7787

\title{
Physiological aspects of corn plants related to mesotrione herbicide selectivity
}

\author{
Ismael Lourenço de Jesus Freitas ${ }^{1}$, Weverton Pereira Rodrigues ${ }^{1}$, Silvério de Paiva Freitas ${ }^{1}$, Jalille \\ Amim Altoé Freitas ${ }^{1}$, Reynaldo Tancredo Amim ${ }^{2}$, Antonio Teixeira do Amaral Junior ${ }^{1}$, Eliemar \\ Campostrini $^{1}$
}

1Centro de Ciências e Tecnologias Agropecuárias, Universidade Estadual do Norte Fluminense (UENF), Avenida
Alberto Lamego 2000, 28013-602 Parque Califrórnia, Campos dos Goytacazes, Rio de Janeiro, Brazil.
${ }^{2}$ Instituto Federal de Educação, Ciência e Tecnologia Fluminense, campus de Cambuci, Estrada Cambuci Km
05, słn, 28430-000 Três Irmãos,Cambuci, Rio de Janeiro, Brazil

*Corresponding author: ismaelljf@yahoo.com.br

\begin{abstract}
The objective of the present study was to assess the physiological aspects related to the activity of mesotrione herbicide at different doses in corn plants. The experiment was performed, in a greenhouse, on UENF 506-8 hybrid grown in $12 \mathrm{~L}$ pots with substrate (2:1 sand and clay). A randomized complete block design in a 3 x 5 factorial scheme, with four replications was used. Plants at fourth leaf stage were exposed to three doses $\left(0,0.15\right.$ and $\left.0.30 \mathrm{~kg} \mathrm{ha}^{-1}\right)$ of herbicide mesotrione. Three, four, five, six and 13 days after application (DAA) of herbicide mesotrione gas exchange and chlorophyll $a$ fluorescence (considering a JIP Test $_{\text {analysis) were }}$ measured. Plant height (PH), leaf area (LA), canopy (CDM) and root dry matter were measured at 28 DAA, when plants were at V12 stage and $c a$. 85 to $90 \%$ grown of its total area. The results showed that UENF 506-8corn hybrid was remarkably tolerant to dose of $0.15 \mathrm{Kg} \mathrm{ha}^{-1}$ without deleterious effects on photochemistry and biochemistry path way, maintaining the values of several $\mathrm{JIP}_{\text {Test }}$ parameters and gas exchange. However, decreases in photosynthetic rate, stomata conductance, and transpiration and several $\mathrm{JIP}_{\text {Test }}$ parameters were observed when the plants were exposed to dose of $0.30 \mathrm{~kg} \mathrm{ha}{ }^{-1}$ although there was no harmful damage on most of the growth parameters. However, dose of $0.15 \mathrm{Kg} \mathrm{ha}^{-1}$ should be recommended since dose as high as $0.30 \mathrm{~kg}$ ha ${ }^{-1}$ caused decrease in CDM.
\end{abstract}

Keywords: Herbicide; Zea mays L.; Phytotoxicity.

Abbreviation: Qa_quinone a, ET_electron transport, DAA_day after application. $A_{-}$photosynthesis rate, $g s_{-}$stomata conductance, $E_{-}$transpiration rate, $\mathrm{C}_{\mathrm{i}} / \mathrm{C}_{\mathrm{a} \_}$internal-to-ambient $\mathrm{CO}_{2}$ concentration ratio, $\mathrm{F}_{\mathrm{v}} / \mathrm{F}_{\mathrm{m}}$ - maximum PSII efficiency, ABS/RC_amount of energy absorbed by the pigments in the PSII antenna complex, per unit of active reaction center, $\mathrm{DI}_{\mathrm{o}} / \mathrm{RC}_{-}$dissipated energy per unit of active reaction center, $\mathrm{RC} / \mathrm{CS}_{\mathrm{o}_{-}}$number of active reaction centres per cross, $\mathrm{ET}_{\mathrm{o}} / \mathrm{CS}_{\mathrm{o}_{-}}$energy distribution ratio per transversal section from sample, PH_plant height, LA_leaf area, CDM_canopy dry matter, RDM_root dry matter.

\section{Introduction}

Brazil is one of the main corn (Zea mays L.) producers with an extensive cultivated area and volume produced of ca.85 million tons in 2014/2015 harvest, with mean yield of 5,716 kg.ha- ${ }^{-1}$ (CONAB, 2016).

Weeds can cause losses in corn yield ranging from 13.1 to more than $85 \%$ depending on the competing species, degree of infestation, times and extension of weed coexistence period, the development crop stage and the climatic conditions (Freitas et al., 2009). Therefore, weed control is an economic necessity and the chemical control has been the most common method used on large areas. However, the efficiency varies among herbicides depending on the environmental conditions, time of application and weed species infesting the crop (Freitas et al., 2014).

Gas exchange measurement is a powerful tool for studying herbicide selectivity/phytotoxicity in corn plants since it demonstrates photosynthetic performance (Lemos et al., 2012). Chlorophyll $a$ fluorescence have been widely used because is a non-destructive method and also allows qualitative and quantitative analysis of the absorption, partitioning and use of the light energy in photosystem II
(PSII) and possible effects on photosynthetic capacity (Mouget and Tremblin, 2002; Netto et al., 2005). This technique has been used to investigate the photochemical and non-photochemical processes which occur during the light absorption and the factors related to the absorption capacity and transference of the light energy through electron transport chain (Genty et al., 1989; Krause and Weis, 1991).().,Changes in the fluorescence signal result from variations in the photochemical and non-photochemical quenching showing either absence or presence of damage on the photosynthesis process (Mouget and Tremblin., 2002).

The $\mathrm{JIP}_{\text {Test }}$ variables are derived from chlorophyll $a$ fluorescence and have been used for in vivo investigations of the performance of the photosynthetic apparatus, since it is sensitive to stress caused by changes in environmental conditions (Martinazzo et al., 2012; Silvestre et al., 2014; Bussotti et al., 2014).The $\mathrm{JIP}_{\text {Test }}$ shows how the photon energy is: 1) absorbed by pigments in photosynthetic antenna system (ABS); 2)dissipated in the antenna system in the form of heat (DI); 3)released in the form of fluorescence (under longer wavelength), 4) channeled to the reaction center to 
reduce quinone a (Qa) e.g., $\mathrm{Qa}$ to $\mathrm{Qa}^{-}(\mathrm{TR})$. $\mathrm{Qa}$ is re-oxidized to create the electron transport (ET), what provides reducing power for carbon assimilation by the Calvin cycle. The JIP $_{\text {Test }}$ parameters have been shown to be adequate for environmental stress studies (Silvestres et al., 2014) and further, can help in plant genetic breeding for different environmental conditions, including corn breeding (Simic et al., 2014).

Mesotrione is a selective and systemic herbicide applied post emergence that may indicated to control weeds infesting corn crop, (Sprague et al., 1999; Rodrigues and Almeida, 2005). Plants absorb the herbicide mainly through the leaf and root organs via apoplastic movement (Mitchell et al., 2001). Plants which are susceptible to mesotrione present leaf chlorosis three days after application evolving to widespread necrosis and death of the plant within 2 weeks (Pallet et al., 1998; Wichert et al., 1999). Overall, corn plants are tolerant to mesotrione herbicide (Johnson et al., 2002), mainly related to the recommended dose. However, high ones can overcome the tolerant mechanisms and cause physiological damage linked to decreases in crop yield. Therefore, we aimed at investigating physiological and growth characteristics in corn plants exposed to different doses of mesotrione herbicide.

\section{Results}

\section{Leaf gas exchange performance}

$A$ values averaged $c a .35 \mu \mathrm{mol} \mathrm{CO} \mathrm{CO}_{2} \mathrm{~m}^{-2} \mathrm{~s}^{-1}$ at three DAA and was similar at doses of 0 and $0.15 \mathrm{~kg} \mathrm{ha}^{-1}$. (Fig 2A) However, there was decrease in carbon assimilation at dose of $0.30 \mathrm{~kg}$ ha $^{-1}$ with photosynthetic rates below $10 \mu \mathrm{mol} \mathrm{CO} \mathrm{Cm}^{-2} \mathrm{~s}^{-1}$, but similar to the control at 13 DAA. Regarding the time, the highest photosynthetic rates occurred at six DAA at doses of 0 and $0.15 \mathrm{~kg} \mathrm{ha}^{-1}$ while at dose of $0.30 \mathrm{~kg} \mathrm{ha}^{-1}$ occurred at 13 DAA (Fig 2A).

Gs values was similar among doses at three DAA with values around $0.13 \mathrm{mmol} \mathrm{H}_{2} \mathrm{O} \mathrm{m}^{-2} \mathrm{~s}^{-1}$, however, plants exposed to dose of $0.30 \mathrm{~kg} \mathrm{ha}^{-1}$ showed lower stomatal aperture values than 0 and $0.15 \mathrm{~kg} \mathrm{ha}^{-1}$ doses from the three up to six DAA (Fig 2B). Gs values were similar among doses at 13 DAA with values around $0.27 \mathrm{mmol} \mathrm{H}_{2} \mathrm{O} \mathrm{m}^{-2} \mathrm{~s}^{-1}$. After three DAA, stomata conductance showed increased values for at all doses, with similar values between 0 and $0.15 \mathrm{~kg}^{-}{ }^{-}$ ${ }^{1}$ doses (Fig2B).

$E$ values were similar among doses at three DAA ( $c a .3$ $\mathrm{mmol} \mathrm{H}_{2} \mathrm{O} \mathrm{m} \mathrm{m}^{-2} \mathrm{~s}^{-1}$ ) however, plants exposed to doses of $0.30 \mathrm{~kg} \mathrm{ha}^{-1}$ showed lower values from the four up to six DAA, but similar values to the control at 13 DAA (Fig 3C). $\mathrm{Ci} / \mathrm{Ca}$ ratio values were similar among doses at three DAA albeit it were greater at four and five DAA ( $c a$. 0.36 and0.38, respectively) at doses of $0.30 \mathrm{~kg} \mathrm{ha}^{-1}$. $\mathrm{Ci} / \mathrm{ca}$ ration values were similar among doses at six DAA (Fig 2D).

\section{Chlorophyll a fluorescence analysis through the JIP ${ }_{\text {Test }}$ and growth}

$\mathrm{ABC} / \mathrm{RC}$ values were similar among doses except at four DAA when the plants exposed to dose of $0.30 \mathrm{~kg} \mathrm{ha}^{-1}$ showed higher values (5) than 0 and $0.15 \mathrm{~kg} \mathrm{ha}^{-1}$ doses (3.5).. Regarding the evaluation period, the highest values were observed at three DAA in plants exposed to dose of 0 and $0.15 \mathrm{~kg} \mathrm{ha}^{-1}$, while the plants exposed to dose of $0.30 \mathrm{~kg} \mathrm{ha}^{-1}$ showed the highest values at four DAA.(Fig 3A).

$\mathrm{DIo} / \mathrm{Rc}$ values were similar at three DAA among doses, except at four DAA when the plants exposed to dose of 0.30 $\mathrm{kg} \mathrm{ha}^{-1}$ showed higher values (ca. 2.5) albeit at five DAA similar values were among dose, with values around 1.3 at 13 DAA. Plants exposed observed to dose of 0 and $0.15 \mathrm{~kg} \mathrm{ha}^{-1}$ showed highest values at three DAA, while the plants exposed to dose of $0.30 \mathrm{~kg} \mathrm{ha}^{-1}$ showed the highest values at four DAA (Fig 3B).

Similar RC/CSo values were observed at three DAA among doses, however, the plants exposed to dose of $0.30 \mathrm{~kg}$ ha ${ }^{1}$ showed lower values at four and five DAA ( $c a .98$ and 118 , respectively). After six DAA similar results o among doses were observed, with values around 120 at 13 DAA. Plants exposed to dose of 0 and $0.15 \mathrm{~kg} \mathrm{ha}^{-1}$ showed the highest values at five and six DAA, while the plants exposed to dose of $0.30 \mathrm{~kg} \mathrm{ha}^{-1}$ the highest values occurred at six and 13 DAA (Fig3C).

ET/CSo values among doses were observed throughout the assessment period and the highest values occurred after the five DAA, with values reaching $c a .140$ at 13 DAA (Fig 3D). Similar values among doses were observed for the $\mathrm{F}_{\mathrm{v}} / \mathrm{F}_{\mathrm{m}}$ ratio (ca. 0.76), except $t$ four DAA when the plants exposed to dose of $0.30 \mathrm{~kg}$ ha showed lower value (ca. 0.5). (Fig 3E). There were no significant differences for NF, PH, RDM and LA traits. However, plants exposed to dose of 0 and $0.15 \mathrm{~kg}$ $\mathrm{ha}^{-1}$ showed the highest values for CDM trait (Table 1).

\section{Discussion}

Corn plants were exposed to doses of mesotrione herbicide $\left(0,0.15\right.$ and $\left.0.30 \mathrm{Kg} \mathrm{ha}^{-1}\right)$ to study the effects of ones on physiological aspect and growth traits. Increase in $A$ values probably occurred by increasing the amount of available light (Fig 1). In fact, increase in photosynthesis rates in corn plants linked to the increase in photosynthetically active radiation were observed, ranging with the phenological stage Lopes et al. (2009). Photosynthesis rates obtained in the present study are similar to those found elsewhere, taking into account different varieties and phenological stages (Lopes et. al., 2009; Lemos et al., 2012). Corn is a mesotrione -tolerant crop due to its metabolic capacity to detoxify these molecules, producing compounds without herbicide activity (Johnson et al., 2002). Indeed plants exposed to dose of $0.15 \mathrm{~kg} \mathrm{ha}^{-1}$ showed no deleterious effects on gas exchange and growth parameters. However, plants exposed to dose of $0.30 \mathrm{~kg}$ ha ${ }^{1}$ showed remarkably decreases in gas exchange-related traits up to six DAA, indicating that metabolic capacity to mesotrione detoxification is dose-dependent

$G s$ and $E$ changes were accompanied by a similar variation pattern in $A$, indicating some stomatal limitation at $0.30 \mathrm{~kg} \mathrm{ha}^{-1}$ dose. Crop yield and stomata functioning are intimately related, since the $\mathrm{CO}_{2}$ uptake is controlled by stomatal aperture (Costa and Marenco,2007).

Transpiration depends mainly on stomata conductance, which decreases according to the incident photosynthetic active radiation and the amount of water available (Bergonci and Pereira, 2002). However, the $C_{i} / C_{a}$ ratio showed similar values at $0.30 \mathrm{~kg} \mathrm{ha}^{-1}$ dose throughout the assessment period, indicating that other limitations (non-stomatal), in addition to those stomatal, contributed to decreases the $A$ values. In fact, increase in photosynthesis rate causes fall in the internal $\mathrm{CO}_{2}$ concentration exercising a strong retro-active effect and can consequently cause fall in the photosynthesis rate (Machado and Lagoa, 1994). ,

Leaf-air vapor pressure gradients are the driving force for the vapor flow consequently affecting the stomata and transpiration system (Taiz and Zaiger, 2013). Thus, some stomata limitation may have occurred for all the doses since the vapour pressure deficit were somewhat high (data not 
Table 1. Analysis of variance for number of leaves (NF), plant height (PH), canopy (CDM) and root dry matter (RDM), and leaf area (LA) from UENF 506-8 cultivar corn plants exposed to doses of 0.15 and $0.30 \mathrm{~kg} \mathrm{ha}^{-1}$ of mesotrione herbicide at 28 days after application.

\begin{tabular}{llllll}
\hline Treatments & $\mathrm{NF}^{\mathrm{ns}}$ & $\mathrm{PH}^{\mathrm{ns}}$ & $\mathrm{RDM}^{\mathrm{ns}}$ & $\mathrm{MSPA}^{* *}$ & $\mathrm{LA}^{\mathrm{ns}}$ \\
\hline $0($ Control $)$ & $8.75 \pm 0.14$ & $0.92 \pm 0.016$ & $8.54 \pm 0.58$ & $14.5 \pm 0.14$ & $1826.5 \pm 93.75$ \\
$0.15 \mathrm{~kg} \mathrm{ha}^{-1}$ & $8.25 \pm 0.12$ & $0.88 \pm 0.091$ & $13.17 \pm 0.65$ & $13.75 \pm 0.37$ & $1839.8 \pm 61.50$ \\
$0.30 \mathrm{~kg} \mathrm{ha}^{-1}$ & $8.25 \pm 0.37$ & $0.86 \pm 0.007$ & $9.19 \pm 0.03$ & $10.75 \pm 0.13$ & $1905.6 \pm 59.61$ \\
\hline $\mathrm{CV}(\%)$ & 12.16 & 5.98 & 31.89 & 6.70 & 15.39 \\
\hline
\end{tabular}

Each value represents the mean $\pm \mathrm{SE}(\mathrm{n}=4) .{ }^{* *}$ significant and ${ }^{\mathrm{ns}}$ not significant by the $\mathrm{F}$ test $(\mathrm{p} \leq 0.01)$. Each value represents a mean $\pm \mathrm{SD}(\mathrm{n}=4) . \mathrm{CV}=\mathrm{coefficient}$ of variation.

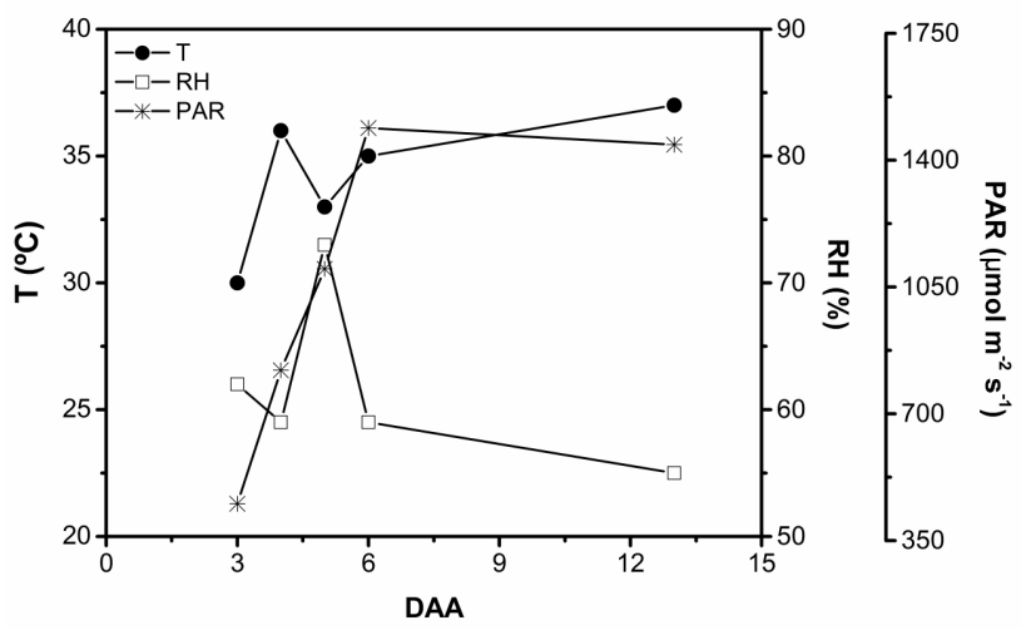

Fig 1. Average temperature (T), relative humidity $(\mathrm{RH})$ and maximum photosynthetic active radiation (PAR) during the experimental period.

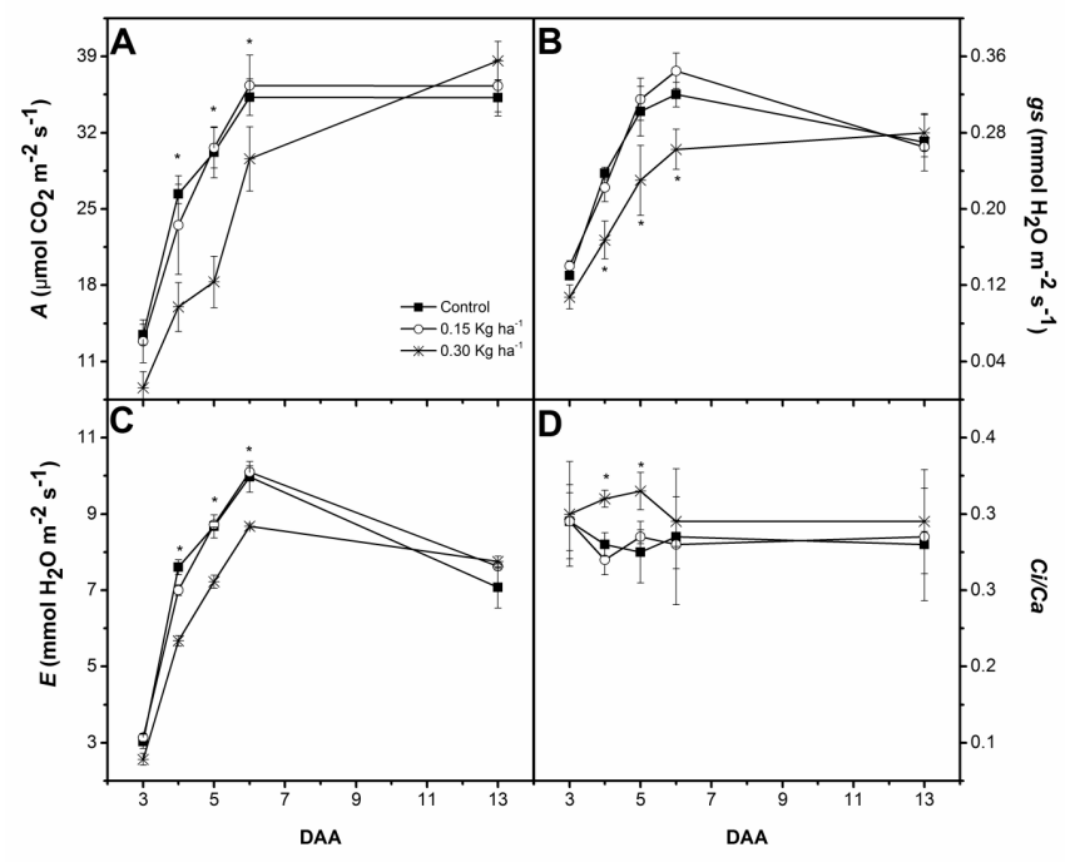

Fig 2. Variation in photosynthesis rate- $A$ - (A), stomata conductance- $g_{s}(\mathrm{~B})$, internal-to-ambient $\mathrm{CO}_{2}$ concentration ratio- $C_{i} / C_{a}$, (C) and transpiration rate- $E$ (D) obtained between $8 \mathrm{AM}$ and 9 AM on UENF 506-8 cultivar plants exposed to doses of 0.15 and $0.30 \mathrm{~kg}$ $\mathrm{ha}^{-1}$ of mesotrione herbicide at three, four, five, six and 13 days after application (DAA). Each value represents the mean $\pm \mathrm{SE}(\mathrm{n}=4)$. *Significant difference. 


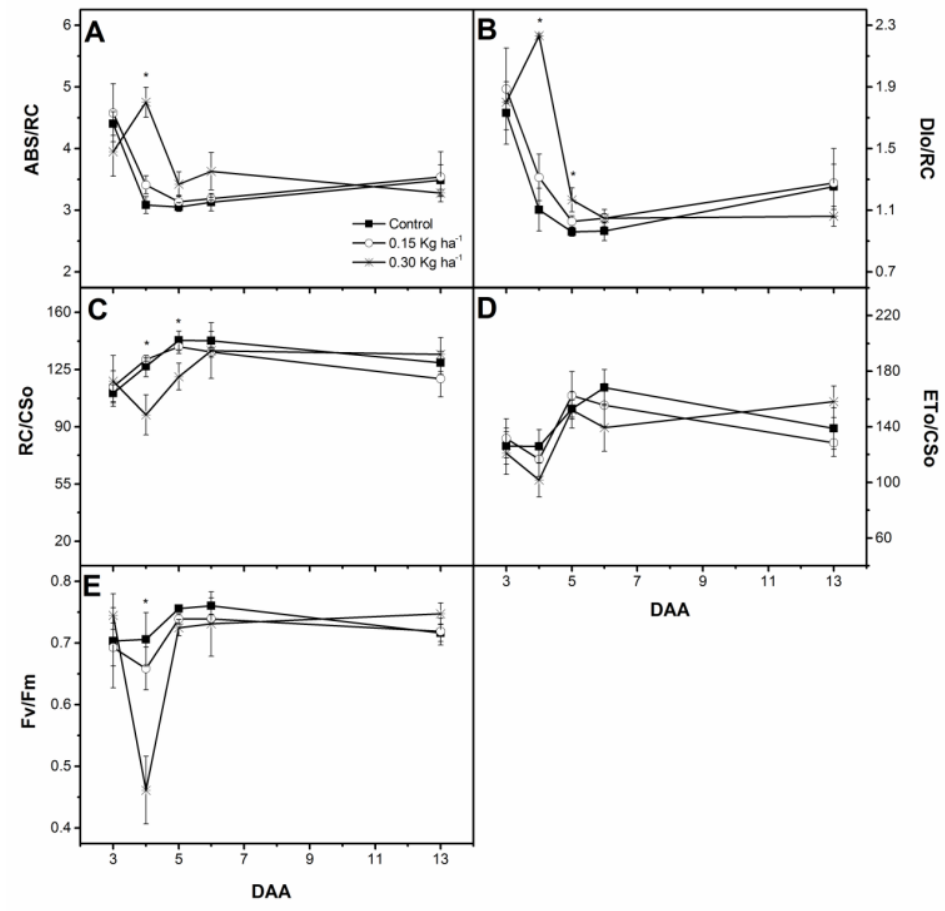

Fig 3. Variation in amount of energy absorbed by the pigments in the PSII antenna complex, per unit of active reaction center$\mathrm{ABS} / \mathrm{RC}(\mathrm{A})$, dissipated energy per unit of active reaction center-DI $/ \mathrm{RC}(\mathrm{B})$, number of active reaction centres per cross-RC/CSo (C) and energy distribution ratio per transversal section from sample $-\mathrm{ET}_{\mathrm{o}} / \mathrm{CS}_{\mathrm{o}}(\mathrm{D})$ and maximum PSII efficiency- $\mathrm{F}_{\mathrm{v}} / \mathrm{F}_{\mathrm{m}}(\mathrm{E})$, obtained between $8 \mathrm{AM}$ and $9 \mathrm{AM}$ on UENF 506-8 cultivar plants exposed to doses of 0.15 and $0.30 \mathrm{~kg} \mathrm{ha}^{-1}$ of mesotrione herbicide at three, four, five, six and 13 days after application (DAA). Each value represents the mean $\pm S E(n=4)$. * Significant difference.

showed), probably due to the high temperatures reported throughout the experimental period (Fig 1). Gas exchange data indicate greater non-stomata limitations on photosynthesis. In fact, several $\mathrm{JIP}_{\text {Test }}$ parameters provide useful information, showing changes in light absorption and partitioning. Plants exposed to dose of $0.30 \mathrm{~kg} \mathrm{ha}^{-1}$ showed a slight trend to decreased values of $\mathrm{ET}_{0} / \mathrm{CS}_{0}$ linked to the increases in $\mathrm{ABS} / \mathrm{RC}$ and $\mathrm{RC} / \mathrm{CS}$ o values. These changes can result in $\mathrm{DI}_{0} / \mathrm{RC}$ increase as observed in Lathyrus genus and act as a protection mechanism to maintain the $\mathrm{F}_{\mathrm{v}} / \mathrm{F}_{\mathrm{m}}$ ratio (Silvestre et al., 2014), which has shown to be sensitive variable and useful for studies of mesotrione in popcorn (Freitas et al., 2014).. However, such changes were not sufficient to maintain $\mathrm{F}_{\mathrm{v}} / \mathrm{F}_{\mathrm{m}}$ ratio in corn plants, showing that the reduction in photosynthesis rates was linked mainly to photochemical limitations. Plants exposed to dose of $0.30 \mathrm{~kg}$ $\mathrm{ha}^{-1}$ showed lower CDM values although it had recovered $\mathrm{F}_{\mathrm{v}} / \mathrm{F}_{\mathrm{m}}$ ratio values at 13 DAA (Table 1). On the other hand, plants exposed to dose of $0.24 \mathrm{~kg} \mathrm{ha}^{-1}$ have not been altered both canopy and root dry matter (Procópio et al. (2006)). Furthermore, Fritsche-Neto et al. (2010) did not observe positive correlation between $\mathrm{CDM}$ and yield. Our data indicate that the recommended mesotrione dose $\left(0.12 \mathrm{~kg} \mathrm{ha}^{-1}\right)$ did not affect the gas exchange and chlorophyll $a$ fluorescence parameters in the UENF 506-8 cultivar, as observed for others corn cultivars (Johnson et al., 2002; Procópio et al., 2006). However, doses as high as $0.30 \mathrm{~kg} \mathrm{ha}^{-1}$, which might be used due to negligence while preparing the solution or lack of information and instructions, affected the photosynthesis pathway. Although the UENF 506-8 cultivar plants recovered its gas exchange and chlorophyll $a$ fluorescence values, the period in which the plants presented the lowest $A$ values can affect yield as observed in popcorn plants (Freitas et al., 2014).

\section{Materials and Methods}

\section{Plant materials conditions and experimental design}

The experiment was carried out in a greenhouse using UENF 506-8 hybrid corn plants grown in $12 \mathrm{~L}$ pots containing substrate $\left(2: 1\right.$ sand and clay) and fertilized with $40 \mathrm{~g} \mathrm{pot}^{-1}$ of N-P-K (4:14:8), ratio with one plant per pot. The plants were irrigated daily and the moisture content was kept close to field capacity. A randomized complete block design in a $3 \mathrm{x}$ 5 factorial scheme, with four replications was used.

Plants at fourth leaf stage were exposed to three doses $(0$, 0.15 and $0.30 \mathrm{~kg} \mathrm{ha} 1$ ) of herbicide mesotrione, using a backpack sprayer, pressurized with $\mathrm{CO}_{2}$, with constant 3.0 $\mathrm{kgf} \mathrm{cm}^{-2}$ pressure and equipped with a Teejet DG 80.02 nozzle, calibrated to apply the equivalent of $237 \mathrm{~L}$ of solution per hectare (ha). The applications were made on days with full sunlight, relative humidity of $c a .75 \%$ and wind speed close to $4 \mathrm{~km} \mathrm{~h}^{-1}$. After three, four, five, six and 13 days after application (DAA) of mesotrione herbicide, gas exchange, chlorophyll $a$ fluorescence (considering a $\mathrm{JIP}_{\text {Test }}$ analysis) were measured

\section{Gas exchange and fluorescence measurements}

Gas exchange (photosynthesis rate- $A$, stomata conductance$g s$, transpiration rate $-E$, as well as the internal-to-ambient $\mathrm{CO}_{2}$ concentration ratio- $\mathrm{C}_{\mathrm{i}} / \mathrm{C}_{\mathrm{a}}$ ) were determined between 8.00 $\mathrm{AM}$ and 9:00 AM, using a portable open-system infrared gas analyser (LI-6200, Li-COR, Lincoln, Nebraska, USA), with leaf measuring area of $c a .6 .8 \mathrm{~cm}^{2}$. The average environmental conditions during the assessment days are shown in Fig1. 
Chlorophyll $a$ fluorescence was evaluated at $8 \mathrm{AM}$ on the same non-detached leaves used for the gas exchange measurements, using a Pocket PEA fluorometer (Hansatech, King's Lynn, UK), taking the measurements on the two last leaves (from the tip to the base of the plant) with one measurement per leaf. The leaf was dark-adapted for $c a$. 30$40 \mathrm{~min}$. using leaf clips (Hansatech) to turn the reaction centres into an "open" (oxidised $\mathrm{Q}_{\mathrm{A}}$ ) state (BòlharNordenkamphet al., 1989). Thereafter, the leaf samples were

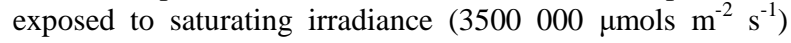
over a $4 \mathrm{~mm}$ diameter area to obtain the Chl $a$ PSII fast fluorescence kinetic transients (OJIP).

In addition to the $F_{v} / F_{m}$ variable which represents the maximum PSII efficiency, some keys parameters of photosynthetic process ( $\mathrm{JIP}_{\text {test }}$ analysis) were obtained using a Biolyzer computer program from chlorophyll $a$ fluorescence (R.J. Strasser, Universityof Geneva, Laboratory of Bioenergetics, Switzerland), according to Strasser et al. (2000): ABS/RC (reflecting the amount of energy absorbed by the pigments in the PSII antenna complex, per unit of active reaction center), $\mathrm{DI}_{\mathrm{o}} / \mathrm{RC}$ (reflecting the dissipated energy per unit of active reaction center), $\mathrm{RC} \mathrm{CS}_{\mathrm{o}}$ (reflecting the number of active reaction centres per cross) and $\mathrm{ET}_{\mathrm{o}} / \mathrm{CS}_{\mathrm{o}}$ (reflecting the energy distribution ratio per transversal section from sample).

\section{Growth parameters and statistical analyzes}

After 28 days DAA when the plants were at V12 stage and with $c a .85$ to $90 \%$ grown of its total area, plant height (PH), leaf area (LA), canopy (CDM) and root dry matter (RDM), were assessed. The biometric data were subjected to analysis of variance and the means compared by the Tukey test $(\mathrm{p} \leq 0.05)$ using the Genes software (Cruz, 2013).

\section{Conclusions}

UENF 506-8 cultivar plants were exposed to two doses of mesotrione, showing that doses as high as $0.30 \mathrm{Kg} \mathrm{ha}^{-1}$ decrease the photosynthetic rates, however the plants recovered ones at 13 DAA. Unlike, plants exposed to dose of $0.15 \mathrm{~kg} \mathrm{ha}^{-1}$ did not present alterations in the gas exchange, chlorophyll a fluorescence and growth parameters. Although plants exposed to doses of $0.30 \mathrm{~kg} \mathrm{ha}^{-1}$ have recovered its gas exchange rate and chlorophyll a fluorescence parameters, a decrease in CDM was observed. . Finally, dose of $0.15 \mathrm{Kg}^{-}{ }^{-}$ 1 should be recommended since under field conditions, environment stress can potentiate to a greater extent the deleterious effects from utilization of dose as high as $0.30 \mathrm{~kg}$ $\mathrm{ha}^{-1}$.

\section{Acknowledgments}

The authors wish to thank Conselho Nacional de Desenvolvimento Científico e Tecnológico (CNPq) for financial support and Universidade Estadual do Norte Fluminense Fazenda Panorama for the experimental area.

\section{References}

Bergonci JI, Pereira PG (2002) Comportamento do potencial da água na folha e da condutância estomática do milho em função da fração de água disponível no solo. Rev Bras Agromet. 10:229-235.

Bolhàr-Nordenkamph HR, Long SP, Baker NR, Öquist G, Schreiber U, Lechner EG (1989) Chlorophyll fluorescence as a probe of the photosynthetic competence of leaves in the field: a review of current instrumentation. Funct Ecol. 3:497-514.

Bussotti F, Desotgiu R, Pollastrini M, Cascio C (2010) The JIP test: a tool to screen the capacity of plant adaptation to climate change. Scand J Forest Res. 25(Suppl 8):43-50.

CONAB. Companhia Nacional do Abastecimento. (2016). Acompanhamento da safra brasileira. Grãos. V. 3 - SAFRA 2015/16- N. 5 - Quinto levantamento. Available in: http://www.conab.gov.br/OlalaCMS/uploads/arquivos/16_0 2_04_11_21_34_boletim_graos_fevereiro_2016_ok.pdf. Accessed March 8, 2016.

Costa GF, Marenco RA (2007) Fotossíntese, condutância estomática e potencial hídrico foliar em árvores jovens de andiroba (Carapaguianensis).Acta Amaz. 37-:229-234.

Cruz CD (2013) GENES - a software package for analysis in experimental statistics and quantitative genetics. Acta SciAgron. 35:271-276.

Freitas ILJ, Rodrigues WP, Amaral Jr AT, Freitas SP, Amim RT, Vittorazzi C, Freitas JAA (2014) Maximum quantum yield of photosystem II to assist in the measurement of herbicide selectivity in popcorn. Plant Sci Today. 1:80-85.

Freitas SP, Moreira JG, Freitas ILJ, Freitas Júnior SP, Amaral Júnior AT, Silva VQR (2009) Fitotoxicidade de herbicidas a diferentes cultivares de milho-pipoca. Planta Daninha. 27:1095-1103.

Fritsche-Neto R, Miranda GV, De Lima RO, Souza LV, Silva J (2010) Herança de caracteres associados à eficiência de utilização do fósforo em milho. Pesqui Agropecu Bras. 45:465-471.

Genty B, Briantais JM, Baker NR (1989) The relationship between quantum yield of photosynthetic electron-transport and quenching of chlorophyll fluorescence. Biochim Biophys Acta. 1:87-92.

Johnson BC, Young BG, Matthews JL (2002) Effect of post emergence application rate and timing of mesotrione on corn (Zea mays) response and weed control. Weed Technol. 16:414-420.

Krause GH, Weis E (1991) Chlorophyll fluorescence and photosynthesis: the basics. Annu Rev Plant Phys. 42:313349.

Lemos JP, Galvão JCC, Silva AA, Fontanetti A, Corrêa MLP, Cecon PR (2012) Morfofisiologia de plantas de milho em competição com picão-preto e trapoeraba submetidas a roçada. Planta Daninha. 30:487-496.

Lopes JP, Machado EC, Deuber R, Machado RS (2009) Análise de crescimento e trocas gasosas na cultura de milho em plantio direto e convencional. Bragantia. 68:839-848.

Machado EC, Lagoa AMMA (1994) Trocas gasosas e condutância estomática em três espécies de gramíneas. Bragantia. 52:141-149.

Martinazzo EG, Silva DM, Bianchi VJ, Bacarin MA (2012) Fluorescência da clorofila $a$ em plantas de pessegueiro da cultivar Maciel enxertada sobre diferentes porta-enxertos. Rev Bras Frutic. 34:678-685.

Mitchell G, BratlettDW, Fraser TE, Hawkes TR, Holt DC, Townson JK, Wichert RA (2001)Mesotrione: a new selective herbicide for use in maize. Pest ManagSci. 57(2):120-128.

Mouget J,Tremblin G (2002) Suitability of the fluorescence monitoring system (FMS,Hansatech) for measurement of photosynthetic characteristics in algae. AquatBot.74:219231.

Netto AT, Campostrini E, Oliveira G, Bressan-Smith R (2005) Photosynthetic pigments, nitrogen, chlorophyll $a$ fluorescence and SPAD-502 readings in coffee leaves. Sci Hortic-Amsterdam. 104:199-209. 
Pallet KE, Little, JP, Sheekey M, Veerasekaran P (1998) The mode of action of isoxaflutole: I. Physiological effects, metabolism, and selectivity. Pestic Biochem Phys. 62:113124.

Procópio SO, Rosenthal MD, Pinto JJO, Jacob Júnior EA. Peres WB, Manica R, Zanatta JF, Cargnelutti Filho A, Sganzerla DC, Carneiro CJ, Amarilla L, Franzini W (2006) Toxicidade do herbicida mesotrione em plantas de milho provenientes de sementes com diferentes formatos $\mathrm{e}$ dimensões. Rev Bras Milho Sorgo. 5:145-152.

Rodrigues BN, Almeida FS (2005) Guia de herbicidas. 5.ed. Londrina: IAPAR.

Silva AA (2002) Biologia e controle de plantas daninhas. Viçosa: DFT. UFV. CD-ROM.

Silvestre S, Araújo SS, Patto MCV, Silva JM (2014) Performance index: An expeditious tool to screen for improved drought resistance in the Lathyrus genus. J. Integr Plant Biol. 56:610-621.

Šimić D, Lepeduš H, Jurković V, Antunović J, Cesar V (2014) Quantitative genetic analysis of chlorophyll $a$ fluorescence parameters in maize in the field environments. J Integr Plant Biol. 56:695-708.
Sprague CL, Maxwell DJ, Wax LM (1999) Compatisons of ZN. 1296 and RPA 201772 for weed control in corn. North Central Weed Sci Soc. 56:223-224.

Strasser RJ, Srivastava A, Tsimilli MM (2000) The fluorescence transient as a tool to characterize and screen photosynthetic samples. In: Yunus MU, Pathre, Mohanty P (eds) Probing Photosynthesis: Mechanisms Regulations and Adaptation. Taylor and Francis. London.

Taiz L, Zeiger E (2013) Fisiologia vegetal. 5. ed. Porto Alegre: ArtMed.

Wichert RA, Bartlett DW, Townson K (1999) Mode of action, absorption, translocation and metabolism of mesotrione in weeds and corn. Proc North Cent Weed Sci. Soc. 54:94-95. 